\title{
BIODEGRADATION OF HAZARDOUS WASTE USING WHITE ROT FUNGUS: PROJECT PLANNING AND CONCEPT DEVELOPMENT DOCUMENT
}

\author{
J. Luey \\ T. M. Brouns \\ M. L. Elliott
}

November 1990

\section{DISCLAIIMER}

\begin{abstract}
This report was prepared as an account of work sponsored by an aguncy of the United States Government. Neither the United States Government nor any agency thereof, nor any of their employees, makes any warranty, express or implied, or assumes any legal liability or responsibility for the accuracy, completeness, or usefulness of any information, apparatus, prorluct, or process disclosed, or represents that its use would not infringe privately owned rights. Reference herein to any specific commercial product, process, or service by trade name, trademark, manufacturer, or otherwise does not necessarily constitute or imply its endorsement, recommendation, or favoring by the United States Government or any agency thereof. The views and opinions of authors expressed herein do not necessarily state or reflect those of the United States Government or any agency thereof.
\end{abstract}

Prepared for the

U.S. Department of Energy

under Contract DE-ACO6-76RLO 1830

Pacific Northwest Laboratory

Richland. Washington 99352

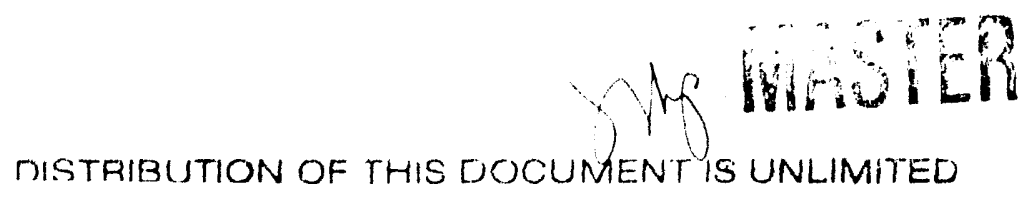




\section{ABSTRACT}

The winte rot fungus Phanerochaete chrysosporium has been shown to effectively degrade pollutants such as trichlorophenol. polychlorinated biphenyls (PCBS), dioxins and other halogenated aromatic compounds. These refractory organic compounds and many others have been identified in the tank waste. groundwater and soil of various U.S. Department of Energy (DUE) sites. The treatment of these refractory organic compounds has been identified as a high priority for DOE's Research, Development, Demonstration. Testing, and Evaluation (RDOT\&E) waste treatment programs. Unlike many bacteria, the white rot fungus $P$. chrysosporium is capable of degrading these types of refractory organics and may be valuable for the treatment of wastes containing multiple pollutants. The objectives of this project are to identify DOE waste problems amenable to white rot fungus treatment and to develop and demonstrate a white rot fungus treatment process for these hazardous organic compounds.

As a first step in this project, this paper describes the current state of technology using the white rot fungus for treatment of refractory organics. and describes the extent of waste problems amenable to white rot fungus treatment at various DOE sites. Based on this work. it is suggested that work in this field concentrate on remediation of DOE sites with high explosivescontaminated soils and aqueous wastes that have organic contamination from multiple refractory compounds. 


\section{CONTENTS}

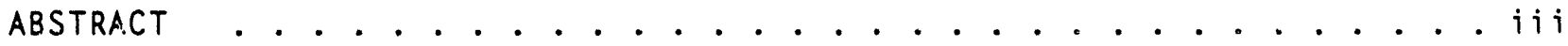

1.0 INTRODUCTION . . . . . . . . . . . . . . . . . . . . 1

2.0 TECHNOLOGY DESCRIPTION ......................... 5

2.1 Treatment of Soils . . . . . . . . . . . . . . . . 5

2.2 Treatment of Aqueous phase Contaminants . . . . . . . . . 8

3.0 WASTE SITE INFORMATION . . . . . . . . . . . . . . . . 11

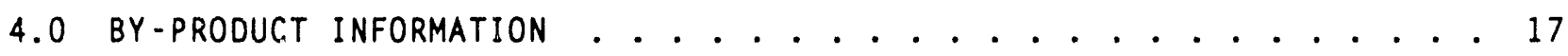

5.0 PERMITTING AND REgULATORY REQUIREMENTS . . . . . . . . . . . . . 21

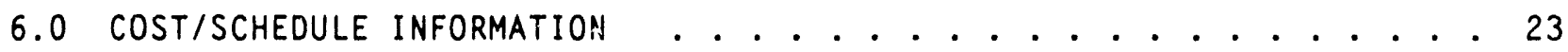

7.0 References ........................... 27 


\section{EIGURES}

2.1 In Situ Soil Treatment Using the White Rot Fungus . . . . . . . . . 6

2.2 Ex Situ Soil Treatment Using the White Rot Fungus . . . . . . . . 7

2.3 Rotating Biological Contactor with the White Rot Fungus . . . . . 8

4.1 Proposed Degradation Pathway for DDT by the White Rot Fungus

Phanerochaete Chrysasporium . . . . . . . . . . . . . 17

4.2 Proposed Degradation Pathway for TNT. . . . . . . . . . . . . 18

6.1 Project Task and Milestone Schedule . . . . . . . . . . . . 24

\section{IABLES}

3.1 Selected Organic Compounds at the Hanford Site . . . . . . . . 12

3.2 Selected Organic Compounds at the Oak Ridge Reservation . . . . . . 12

3.3 Selected Organic Compounds at the Savannah River Site . . . . . . 13

3.4 DOE-DP Sites with High Explosives................. 13

3.5 Organic Compounds Found at DOE Sites . . . . . . . . . . . . . 14

3.6 DOE Sites with Organic Contamination . . . . . . . . . . . 15

6.1 Funding Levels by fiscal Year . . . . . . . . . . . . . . 25 


\subsection{INTRODUCTION}

Liquid wastes containing radioactive, hazardous, organic and regulated chemicals have been generated throughout the $40+$ years of operations at various U.S. Department of Energy (DOE) sites. These wastes were released into the environment via trenches, landfills, pipes and accidental spills, contaminating large volumes of soil and groundwater. Elements of the discharged wastes include polychlorinated biphenyls (PCBs). trinitrotoluene (TNT) and other refractory organic compounds such as trichloroethylene (TCE). carbon tetrachloride, and chloroform. Current DOE policy prohibits the disposal of contaminated liquids directly to the environment, and remediation of existing contaminated groundwater, as well as soils, may be required. A treatment based on the biological mineralization of organic contaminants using a white rot fungus is a promising technology for the simultaneous removal of many organic compounds from contaminated systems.

Biological mineralization is the conversion of a toxic substrate to carbon dioxide and inorganic products through the use of microorganisms (i.e.. bacteria, fungi, and algae). Bacterial consortiums are the most commonly used microorganisms for the treatment of a wide range of organic compounds found in wastewater streams: however, they have not been as effective on such refractory organic contaminants as 1,1-bis(4-chloropheny 1)-2,2.2 trichloroethane (DDT) (Bumpus and Aust 1987) and PCBs (Eaton 1985). Such compounds require organisms capable of degrading aromatic derivatives and/or halogenated aliphatic hydrocarbons. Examples of such organisms include bacterial strains of Flavobacteriumi (Crawford and Mohn 1985) and Arthrobacter (Edgehill and Finn 1983), which have demonstrated mineralization of pentachlorophenol (PCP) in soil, and the white rot fungus Phanerochaete chrysosporium, which has shown the potential to degrade a host of organic compounds including chloroanilines (Arjmand and Sandermann 1985). DDT (Bumpus and Aust 1987: Kohler et al. 1988; Rosiers 1987), anthracene oil (Bumpus 1989). Aroclor 1254 (a polychlorinated biphenyl) (Eaton 1985). PCP (Lamar, Glaser and Kirk 1990; Mileski et al. 1988) and TNT (Fernando, Bumpus and Aust 1990).

The lack of selectivity of the white rot fungus allows the use of a single organism for treating a mixture of organic compounds, as opposed to the standard use of bacterial consortiums for treating multicomponent contaminants. The nonspecific, aerobic degradative ability of the white rot fungus has been attributed to an extracellulary secreted iigninase enzyme 
system that is initiated when the fungus is nitrogen starved (Bumpus 1989: Hammel. Kalyanaraman and Kirk 1986; Kohler et al. 1988; Mileski et al. 1988; Rosiers 1987). The complex structure of lignin probably accounts for the flexibility of these enzymes, thus allowing the oxidation of a wide variety of structurally diverse compounds such as polycyclic aromatic hydrocarbons. dibenzo(p)dioxins and polychlorinated phenols and biphenyls.

Although it is not naturally found in the soil, the white rot fungus has nevertheless shown the ability to degrade contaminants in a soil medium (Arjmand and Sandermann 1985: Bumpus and Aust 1987: Bumpus 1989: Eaton 1985; Fernando, Bumpus and Aust 1990; Lamar, Glaser and Kirk 1990; Mileski et al. 1988; Rosiers 1987). Experimental designs usually involve placing fungus impregnated wood chips in soil with an organic pollutant. Organic pollutants radiolabeled with carbon-14 are used to demonstrate the degree of mineralization. while degradation by-products are determined by analyzing compounds found in an organic solvent extract. In addition to wood chips and wood by-products. corncobs have also been shown to be effective as a support for the white rot fungus (Fernando, Bumpus and Aust 1990).

Factors affecting the ability of the white rot fungus to degrade organic pollutants in situ include the nitrogen content. water potential and manganese concentration of the soil (Kohler et al. 1988: Lamar et al. 1987: Lamar. Glaser and Kirk 1990). Access to the organic contaminant and the activity level of the white-rot ligninase system also affects the degradative ability of the fungi. Optimization of these factors will maximize the potential of any soil remediation technology involving the white rot fungus.

Aqueous phase treatment is also possible using the white rot fungus. Lewandowski. Armenante and Pak (1990) found that the tast reactor design for treating aqueous streams involved the use of immobilized fungi. The primary factors limiting the degradative ability of the fungi in an aqueous phase are the fungi's access to oxygen and the mass transfer resistance. which prevents extensive contact between the organic contaminant and the growing fungi.

The primary remediation goal for soils, groundwaters and wastewaters at DOE sites is to reduce concentrations of organic contaminants to acceptable levels (i.e.. levels that meet federal. state and local guidelines). On-site biological treatment processes that completely destroy the contaminants are of greatest benefit. On-site treatment of organic pollutants greatly reduces the risk to the public and workers by reducing the risk associated with 
transporting contaminated material. In situ treatment of soils and on-site groundwater treatment minimizes worker exposure by eliminating the need for excavation and transportation of the contaminants. By minimizing the need for excavation, the cost for treating contaminated soils is greatly reduced. Soils that can be treated on-site may require excavation: however, off-site transportation costs and hazards associated with disposal or incineration are eliminated. Biological treatment is a cost-effective method for destroying hazardous organic constituents with relatively low capital investment and operating costs.

The goal of this project is to develop a bioremediation system that uses the organic degradative capabilities of the white rot fungus Phanerochaete chrysosporium for treating refractory organic cortaminants found at various DOE sites. The approach to be used includes conducting bench-scale tests to collect engineering data, designing and installing a pilot-scale system based on these data, and operating the pilot-scale system to demonstrate the process on actual soils and groundwaters. The project duration is estimated to be five years. The project was initiated in fiscal year (FY) 1990.

This project plannirg document will be used as a planning tool for completing the work that has been initiated. It includes a description of the technology, waste information, permit requirements and cost/schedule information. 


\subsection{IECHNOLOGY DESCRIPIION}

Conventional processes for the biological detoxification of hazardous organic wastes are based on the use of bacterial consortia. These waste treatment systems have generally been unable to rapidly metabolize aromatic compounds, along with their derivatives and other refractory organic contaminants (i.e.. chlorinated aliphatic hydrocarbons). Phanerochaete chrysosporium, a white rot fungus in the class Basidiomycetes, has been shown to be capable of degrading many refractory organic compounds. The mechanism identified for this phenomenon is based on a nonselective extraceliular enzyme that the white rot fungus uses to degrade lignin. a structural component of wood. Because of the complexities of the lignin structure, this enzyme system is very flexible in the types of organic compounds it reacts with and degrades.

Additional discussion on the conceptual methods for treating soil. both in situ and ex situ, and groundwater with the white rot fungus will be discussed in the following subsections.

\subsection{Ireatment of Soils}

The white rot fungus is not naturally found in the soil and does not compete well when alone with the native microflora of nonsteriie soils. To aid the fungus, wood chips are commoniy used as both a support and growth media for the fungi. Wood by-products or other lignin-containing materials may also be used (Rosiers 1987). Impregnating lignin-containing materials with the white rot furigus is the first step for proven biological remediation of contaminated soils (Fernando. Bumpus and Aust 1990: Rosiers 1987).

Figure 2.1. illustrates the concept of in situ bioremediation of soils. This concept involves the use of standard land farming equipment to mix fungusimpregnated material into the contamination site. Hixing performs two very important functions: 1 ) it aerates the treatment site and provides oxygen for the aerobic microorganisms, and 2) it improves the contacting of the microorganisms with the contaminant they are to degrade. Nutrients may have to be added to the soil to maximize the performance of the fungi, especially in situations where the level of contamination is too low to sustain fungal growth. Additional batches of inoculum may also be added to improve the amount of contact between microorganisms and contaminants, as well as to 


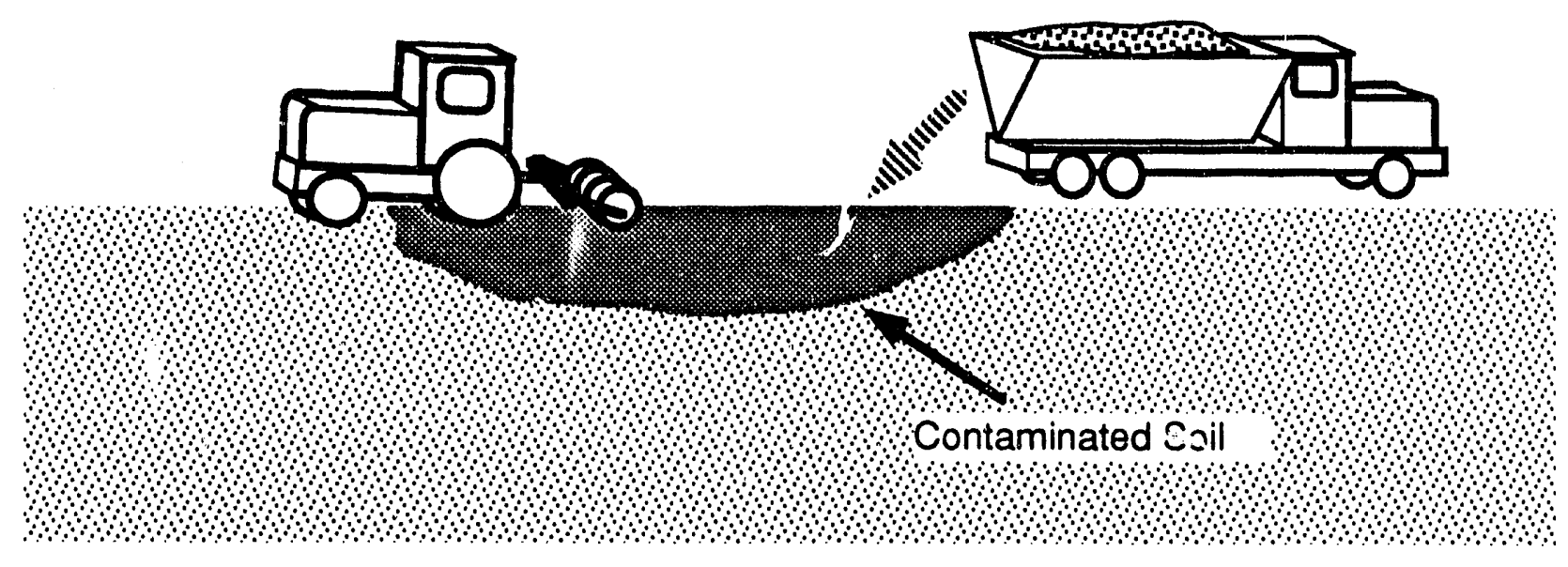

EIGURE 2.1. In Situ Soil Treatment Using the White Rot Fungus

improve the viability of the white rot fungus with native microflora. In some cases the depth of organic contamination in a soil column may be too great for effective in situ treatment. Figure 2.2 illustrates the ex situ treatment of a contaminated site. which first requires the excavation of the treatment site soi i into an adjacent lined trench. The soil in the trench is then mixed with fungal inoculum and treated in the same way as sites that are treated in situ. An obvious drawback to ex situ treatment of contaminated soils is the added costs of excavation and preparation of a lined trench area. However. excavation followed by on-site treatment is a more attractive alternative than excavation and transportation to an approved disposal or incineration site.

Mixing of fungi-impregnated material with contaminated soils is the current state of technology for both in situ and ex situ bioremediation of contaminated soils. Development of an in situ treatment that does not require mixing is an attractive, cost-reducing alternative and may be recuired in some instances (e.g.. situations involving explosives at levels of contamination that are close to their explosive limits, making the use of heavy equipment unsafe). Such a treatment should provide a delivery system for the oxygen. microorganisms, and nutrients that makes minimal use of machinery and provides an opportunity for good contact of the organic contaminants with the degrading organisms. 


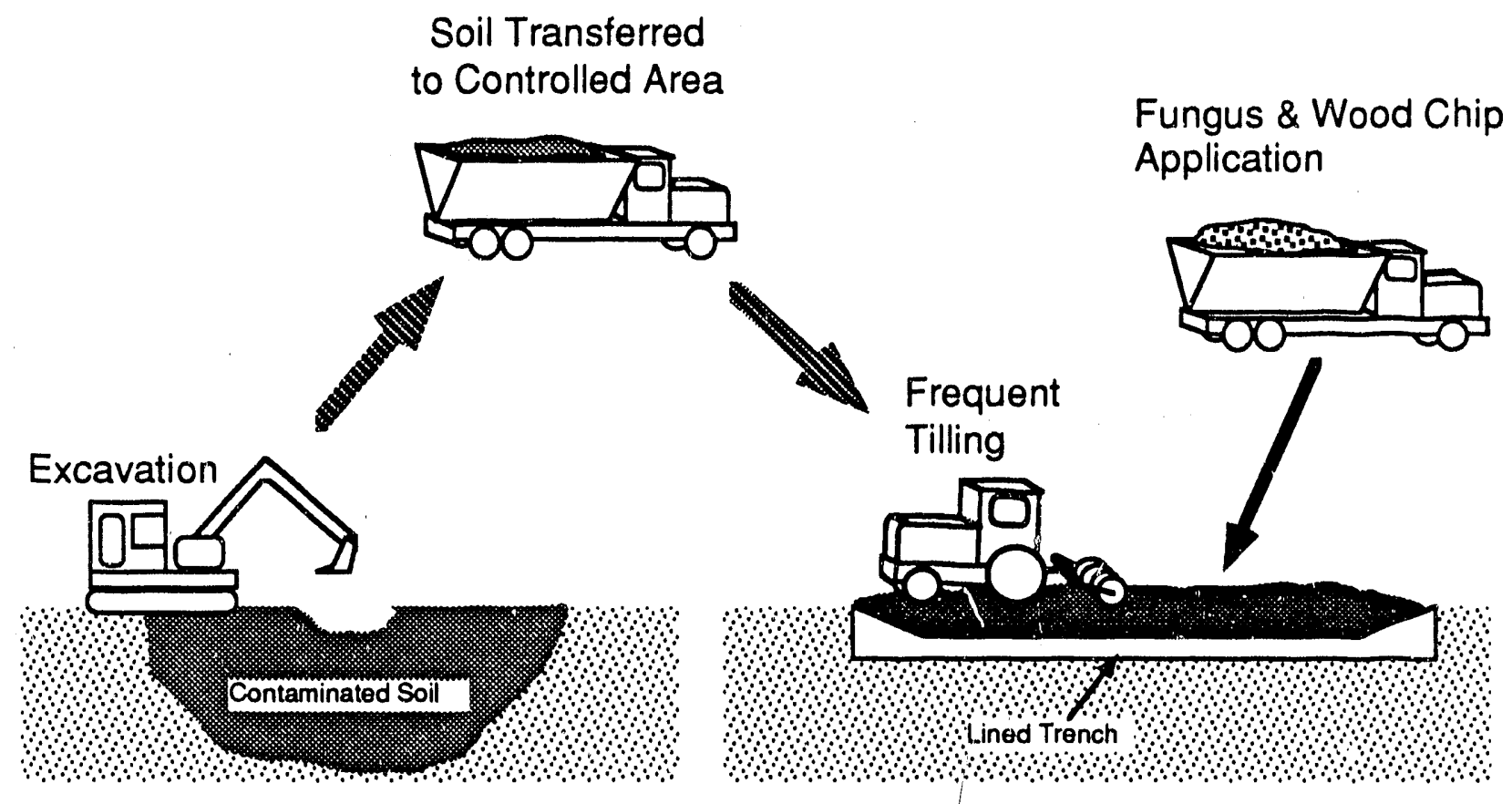

EIGURE 22. Ex Situ Soil Treatment Using the White Rot Fungus

Delivery of the white rot fungus, nutrients and oxygen through undergrcund injection tubes holds promise, but imited mobility of the microorganisms through the soil creates a problam of either poor contact with organic contaminants or the need for many tubes. Use of excess liquid to mobilize the fungus is a possible solution, butt this option also presents two potential problems: 1) excess liquid may mobilitze the organic contaminants to the point where they can enter the groundwater and 2) fungal, or bacterial. growth at the openings of the injection tubes fould greatly increase the pumping requirements for the liquid system. the latter problem could be addressed by supplying nutrients at amounts that are toxic to the microorganisms at the coricentrations at the thble openings, or by supplying nutrients in a time-released form to reduce the rate of microbial growth.

Possible alternatives to the exclusive $4 \$ s$ of the white rot fungus for treatment of contaminated soils include 1) tile use of a cursortium of fungus and bacteria to obtain a more complete minerthlization of contaminating organic compounds: 2) use of anaerobic microorganisms that cian degrade refractory organic compounds (eliminating the need for mixing the treatment site): and 3 ) combining in situ or ex situ soil washing whth aqueous phase fungal treatment. 


\subsection{Ireatment of Aqueous-phase Contaminants}

The degradation and/or mineralization of refractory organics by the white rot fungus Phanerochaete chrysosporium has been shown to be more effective in an aqueous phase than in a soil column (Fernando. Bumpus and Aust 1990. Lamar. Glaser and Kirk 1990). An aqueous system removes two important limiting conditions that exist in a soil column: 1) aqueous phase treatment allows better contact between the contaminant and the degrading microorganism. and 2) nutrient limitations are overcome through better distribution in an aqueous phase. These two factors become very evident in the design of reactor vessels that are used to treat contaminated wastewater or groundwater.

Lewandowski. Armenante and Pak (1990) evaluated different reactor designs for the treatment of 2-chlorophenol by the white rot fungus Phanerochaete chrysosporium and found that the performance of reactors that used an immobilized fungus was far superior to reactors in which the fungus was freely suspended. A packed-bed reactor with a porous silica support and a well-mixed reactor with alginate beads as the supporting medium were the best-performing designs.

Figure 2.3 illustrates the use of a rotating biological contactor for the ex situ teatment of groundwater. The rotating biological contactor contains

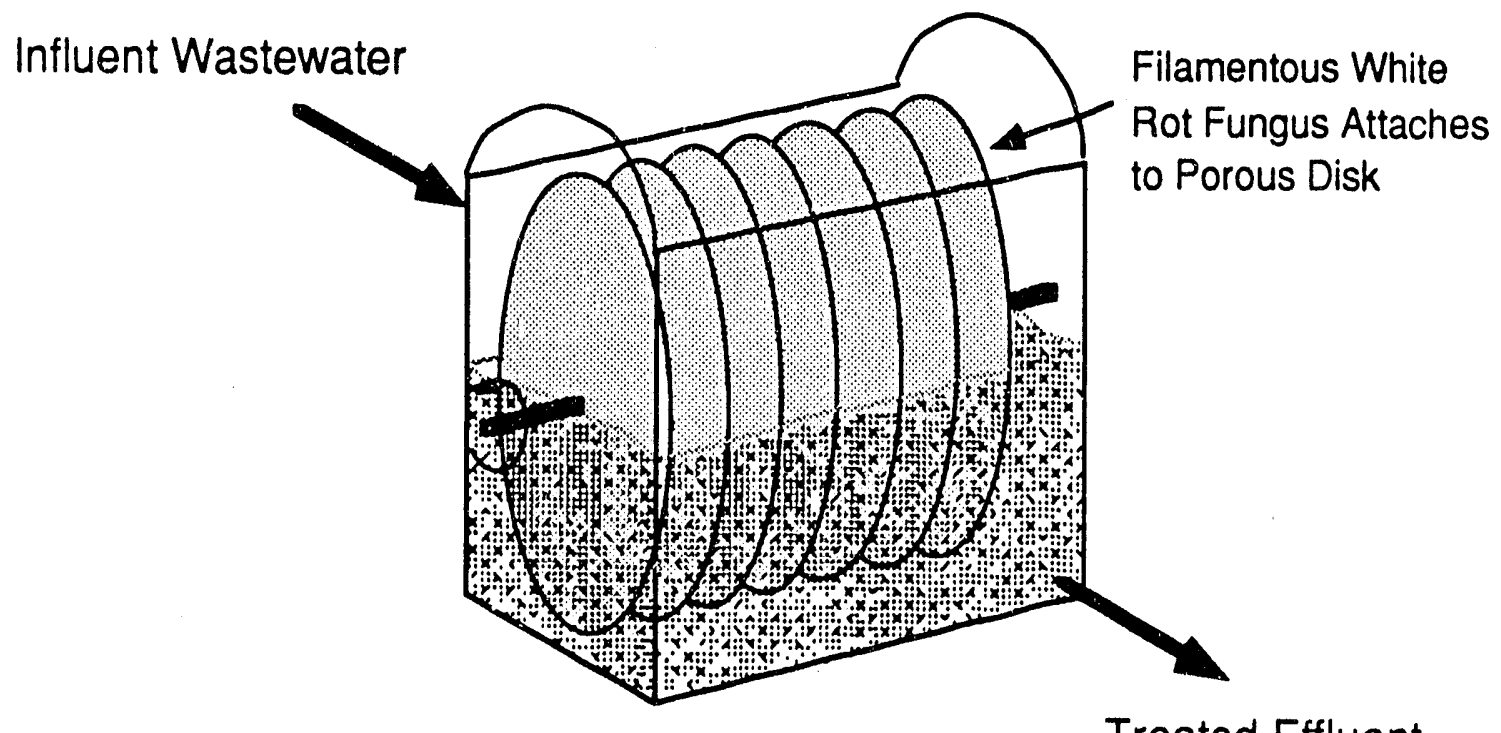

Treated Effluent

EIGURE 2.3. Rotating Biological Contactor with the white Rot Fungus 
many of the features of Lewandowski's well-mixed reactor. With this design. filamentous white rot fungus atliches to a porous disk that rotates through a contaminated stream. Influent waste water enters the contactor, contacts the white rot fungus for a period of time and is then pumped from the contactor. The contactor can operate in either a continuous or semi-batch mode. Batch operation is not efficient unless nutrients can be added to sustain the growth of fungi, thus making the operation semi-batch. Because the white rot fungus has been shown to be more effective in degrading aqueous contaminants than soil contaminants, the treatment of soils may involve leaching the soil contaminants into an aqueous phase. Current pump-and-treat methods exist that will allow the addition and removal of an aqueous stream to the soil column. However. since natural flows of water through the soil column remove the refractory organics slowly. it is unlikely that pure water will sufficiently leach the organics from the soil. Choi and Aomine (1974a and 1974b) found that $\mathrm{pH}$ was a major factor controlling the adsorption of pentachlorophenol $(P C P)$ to soil. suggesting that adjusting the $\mathrm{pH}$ may improve leaching of refractory organics from a soil column. 


\subsection{WASIE SITE IMFORMATION}

Comprehensive information on the levels of organic contaminants at various $D O E$ sites was not available at the time of this writing. This sectinn provides a general overview of selected contamination problems in the $D O E$ system that may be ainenable to treatment by the white rot fungus Phanerochaete chrysosporium.

Tables 3.1-3.3(1) list the refractory organic compounds on the Hanford. Savannah River and Oak Ridge sites that have been shown. or are believed to be. amenable to treatment by the white rot fungus. The criteria for inclusion of these organic compounds falls into two categories: 1) the compcund was selected if it was present at levels above the federal guidelines. if it is not presently regulated, or if a regulatory limit is not currently specified: and 2) the contaminant is found in an environmental medium that is likely to be conducive to treatment by the white rot fungus. Hanford in-tank waste is included since it is believed that the organic compounds found in some in-tank mixed waste can be destroyed to produce a low-level waste.

Table 3.4 highlights those DOE sites that contain high explosives identified as potential health hazards, along with the identified compounds. High explosives contamination is present at both DOE and DOD facilities.

Current treatment at $D O D$ facilities involves costly incineration of $\mathrm{HE}$. contaminated soil. Comrosting is a potential alternative to incineration, but has not yet been found to be cost effective (Remediation Technologies. Inc.. 1990). A 1989 U.S. Army Toxic and Hazardous Materials Agency (USATHAMA) workshop on compostin's icentified fungal treatment as a possible composting alternative. a conclusion supported by the recent observation of TNT degradation by the white rot fungus (Fernando. Bumpus and Aust. 1990). The primary advantage of fungal treatment is the potential for complete inirieralization. which is generally not attained with conventional composting (Roy F. Weston. Iric. 1988).

Table 3.5 lists the various organic compounds found at those DOE sites listed in Table 3.6. Table 3.5 does not include all organic comfounds found on DOE sites. Dut lists those compounds believed to be amenable to treatment by the white rot fungus.

(1) G. R. Bilyard. R. J. Bischof, J. Joseph. J. F. Keller, and M. V. Norton. March 1990. Draft Report. "Chemicals and Radioactive Substances Important to Operations and Activities at Department of Energy Sites." 
IABLE 3.1. Selected Organic Compounds at the Hanford Site

\begin{tabular}{|c|c|c|c|c|}
\hline Compound & $\begin{array}{c}\text { Environmental } \\
\text { Medium(a) }\end{array}$ & $\begin{array}{l}\text { Selection } \\
\text { criteria }\end{array}$ & $\begin{array}{c}\text { Criterion } \\
\text { Basis }\end{array}$ & Reference \\
\hline Benzene & $T W$ & NS & NS & Klemm 1988 \\
\hline 2.40 & TW & NS & NS & Klemm 1988 \\
\hline Dibutylphthalate & TW & NS & NS & U. S. DOE 1987 \\
\hline Endrin & TW & NS & NS & Klemm 1988 \\
\hline Lindane & TW & NS & NS & K1 emm 1988 \\
\hline \multirow[t]{2}{*}{ Naphthylamine } & TW & NS & NS & Klemm 1988 \\
\hline & GW & NS & NS & PNL 1987 \\
\hline Phthalic acid & $T W$ & NS & NS & U. S. DOE 1987 \\
\hline 2.4.5-TP Silvex & $T W$ & NS & N'S & Klemm 1988 \\
\hline Toluene & TW & NS & NS & Klemm 1988 \\
\hline Toxaphene & $T W$ & NS & NS & $\mathrm{K} 1 \mathrm{emm} 1988$ \\
\hline xylene & $T W$ & NS & NS & Klemm 1988 \\
\hline
\end{tabular}

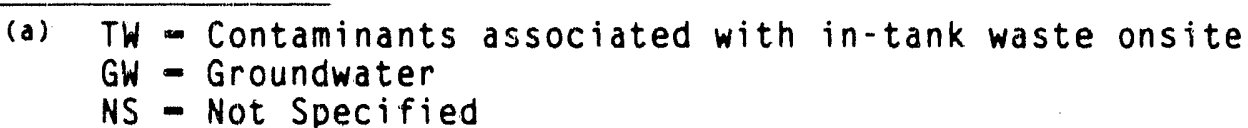

IARLE 3.2. Selected Organic Compounds at the Oak Ridge Reservation

\begin{tabular}{|c|c|c|c|c|}
\hline Compound & $\begin{array}{c}\text { Environmental } \\
\operatorname{Medium(a)}\end{array}$ & $\begin{array}{l}\text { Selection } \\
\text { criteria }\end{array}$ & $\begin{array}{c}\text { Criterion } \\
\text { Basis }\end{array}$ & Reference (b) \\
\hline Benzene & GW & $0.005 \mathrm{mg} / \mathrm{L}$ & NS & Martin Marietta 1989 \\
\hline Benzo[a]anthracene & GW & NS & NS & Martin Marietta 1989 \\
\hline \multicolumn{5}{|l|}{ Bis(2-ethylhexyl) } \\
\hline Phthalate & GW & NS & NS & Martin Marietta 1989 \\
\hline Chrysene & GW & NS & NS & Martin Marietta 1989 \\
\hline Diethyl phthalate & GW & NS & NS & Martin Marietta 1989 \\
\hline Naphthalene & GW & NS & NS & Martin Marietta 1989 \\
\hline \multicolumn{5}{|l|}{ Polychlorinated } \\
\hline Biphenyls & so & $22.700 \mathrm{~kg}$ & NS & SARA 1986 \\
\hline Tetrachlorobenzene & GW & NS & NS & Martin Marietta 1989 \\
\hline Toluene & GW & NS & NS & Martin Marietta 1989 \\
\hline (a) $\begin{aligned} & \text { GW }=\text { Grou } \\
& \text { SO }=\text { Soil } \\
& \text { NS }=\text { Not } \\
& \text { (b) SARA Cita }\end{aligned}$ & $\begin{array}{l}\text { undwater } \\
1 \\
\text { Specified } \\
\text { ation provided }\end{array}$ & Selection & Criteria. & \\
\hline
\end{tabular}


IABLE 3.3. Selected Organic Compounds at the Savannah River Site

\begin{tabular}{|c|c|c|c|c|}
\hline Compound & $\begin{array}{c}\text { Environmental } \\
\text { Medium(a) }^{\text {Mediug }}\end{array}$ & $\begin{array}{l}\text { Selection } \\
\text { criteria }\end{array}$ & $\begin{array}{l}\text { Criterion } \\
\text { Basis (b) }\end{array}$ & Reference (c) \\
\hline \multicolumn{5}{|c|}{ Bis(2-ethylhexyl)- } \\
\hline Phthalate & so & $4000.0 \mathrm{ppm}$ & NS & Looney et al. 1987 \\
\hline Benzene & GW & $2.5 \mu \mathrm{g} / \mathrm{L}$ & $R B / T B$ & 50 FR 46902 \\
\hline \multirow[t]{2}{*}{2.40} & GW & $100.0 \mu \mathrm{g} / \mathrm{L}$ & $R B / T B$ & 40 CFR 141 \\
\hline & so & $20.0 \mathrm{ppm}$ & NS & Looney et a 1. 1987 \\
\hline \multirow[t]{2}{*}{ Endrin } & GW & $0.2 \mu \mathrm{g} / \mathrm{L}$ & $\mathrm{RB} / \mathrm{TE}$ & 40 CFR 141 \\
\hline & so & $0.04 \mathrm{ppm}$ & NS & Looney et a 1. 1987 \\
\hline Hexachlorobiphenyl & so & $1.0 \mathrm{ppm}$ & NS & Looney et a1. 1987 \\
\hline Lindane & GW & $4.0 \mu \mathrm{g} / \mathrm{L}$ & $R B / T B$ & 40 CFR 141 \\
\hline Pentachlorobiphenyl & so & $1.0 \mathrm{ppm}$ & NS & Looney et al. 1987 \\
\hline \multicolumn{5}{|l|}{ Polychlorinated } \\
\hline Biphenyls & So & NS & NS & Looney et al. 1987 \\
\hline \multirow[t]{2}{*}{ 2,4.5-TP Silvex } & GW & $10.0 \mu \mathrm{g} / \mathrm{L}$ & NS & U. S. EPA 1976 \\
\hline & So & $2.0 \mathrm{ppm}$ & NS & Looney et a 1. 1987 \\
\hline Tetrachlorobiphenyl & so & $1.0 \mathrm{ppm}$ & NS & Looney et al. 1987 \\
\hline \multirow[t]{2}{*}{ Toxaphene } & GW & $5.0 \mu \mathrm{g} / \mathrm{L}$ & $R B / T B$ & 40 CFR 141 \\
\hline & so & $1.0 \mathrm{ppm}$ & NS & Looney et al. 1987 \\
\hline
\end{tabular}
(a) GW - Groundwater
SO - Soil
(b) RB - Risk Based
TB - Technology Based
NS - Not Specified
(c) FR and CFR citations provide the Selection Criteria.

IABLE 3.4. DOE-DP Sites with high Explosives

DOE-DP Site

Los Alamos National Laboratory (LANL)
Lawrence Livermore National Laboratory (LLNL)
Pantex Facility

High Explesives

di-N-butyl phthalate

HMX - 1,3,5,7-Tetrazocine, Octagen

TITB-3HN $2-3 \mathrm{NO}_{2}$-Benzene

IETN - Pentaerythrite tetranitrate

RDX - Hexahydro-1.3.5-trinitro-1,3.5-triazine

TNT - Trinitrotoluene 
IABLE 3.5. Organic Compounds Found at DOE Sites (Strenge 1989)

RDX. Hexahydro-1,3,4-Trinitro-1,3,5-Triazine

Endrin. Hexadrin

4-Aminobipheny1. 4-Biphenylamine

Gamma-hexachlorocyclohexane, Lindane, Gamma-BHC, Gamma-HCH, BHC 2-Naphthlamine, USAF CB-22

Benz(a)anthracene, 1.2-benzanthracene

Anthracene. Paranaphthalene

Phenanthrene

Aniline, Aminobenzene. Phenylamine

2-Methyiphenol, 0-cresylic acid

p-nitroaniline. Paranitroaniline (solid)

$1,2,4,5-$ Tetrachlorobenzene

1.2 Dichlorobenzene, Dowtherm $E$

1.4-Dichlorobenzene, Paracide, PDB

1,3-0ichlorobenzene

Dimethyl phthalate. Solvarone

2,3,4,6,-Tetrachlorophenol, Dowicide 6

TNT. Trinitrotoluene (dry)

Aroclor 1016. PCB 1016

Pentachloronitrobenzene. Tritisan

2,4-D. Amidox. Estone, Fernesta

2.4,6-Trichlorophenol, Omal

Chrysene. Benz(a)phenanthrene

Initiating explosive pentaerythrite tetranitrate. PETN

1.3,5,7-Tetrazocine, Octahydro-1,3,5,7-tetranitro, Octagen

Xylene. Benzene (dimethyl)

DDT. Kopsol, Dicophane

Toluene. Toluol

Chlarobenzene. Phenyl chloride

Dibenzol $(a, h)$ anthracene. 1,2,5,6-DBA

Hexachlorodibenzo-p-dioxin

$2,3,7,8$-Tetrachlorodibenzo-p-Dioxin. TCDD

Di-n-octyl phthalate

2,4-Dichlorophenol, DCP. NCI-C55345

Pyrene, Benzo(def)phenanthrene

Hexachiorobenzene

P-chloroaniline, 1-amino-4-chlorobenzene

0 -Nitroaniline, Devol orange $B$

2,4-Dinitrotoluene, DNT

2-Chloronaphthalene

Silvex, Propon. Aqua-vex

Pentachlorophenol. Permite, EP 30

Aroclor. PCB (General Classification). Therminal

Dicofol. DTMC, Carbax, Kelthane

2-Chlorophenol. Phenol

4-Chlorophenyl phenyl ether

TATB 3NH2-3NO2-BNZNE

DDD. Rhothane

2,4,5-Trichlorophenol, Nurelle

Pentachlorobenzene, $Q C B$

1.2.4-Trichlorobenzene, unsym-Trichlorobenzene

Naphthalene. Naphthal in

Toxaphene, Phenacide, Motox 
IABLE 3.6. DOE Sites with Organic Contamination. DOE sites included in the DOE Environmental Survey (Droppo et al. 1990)

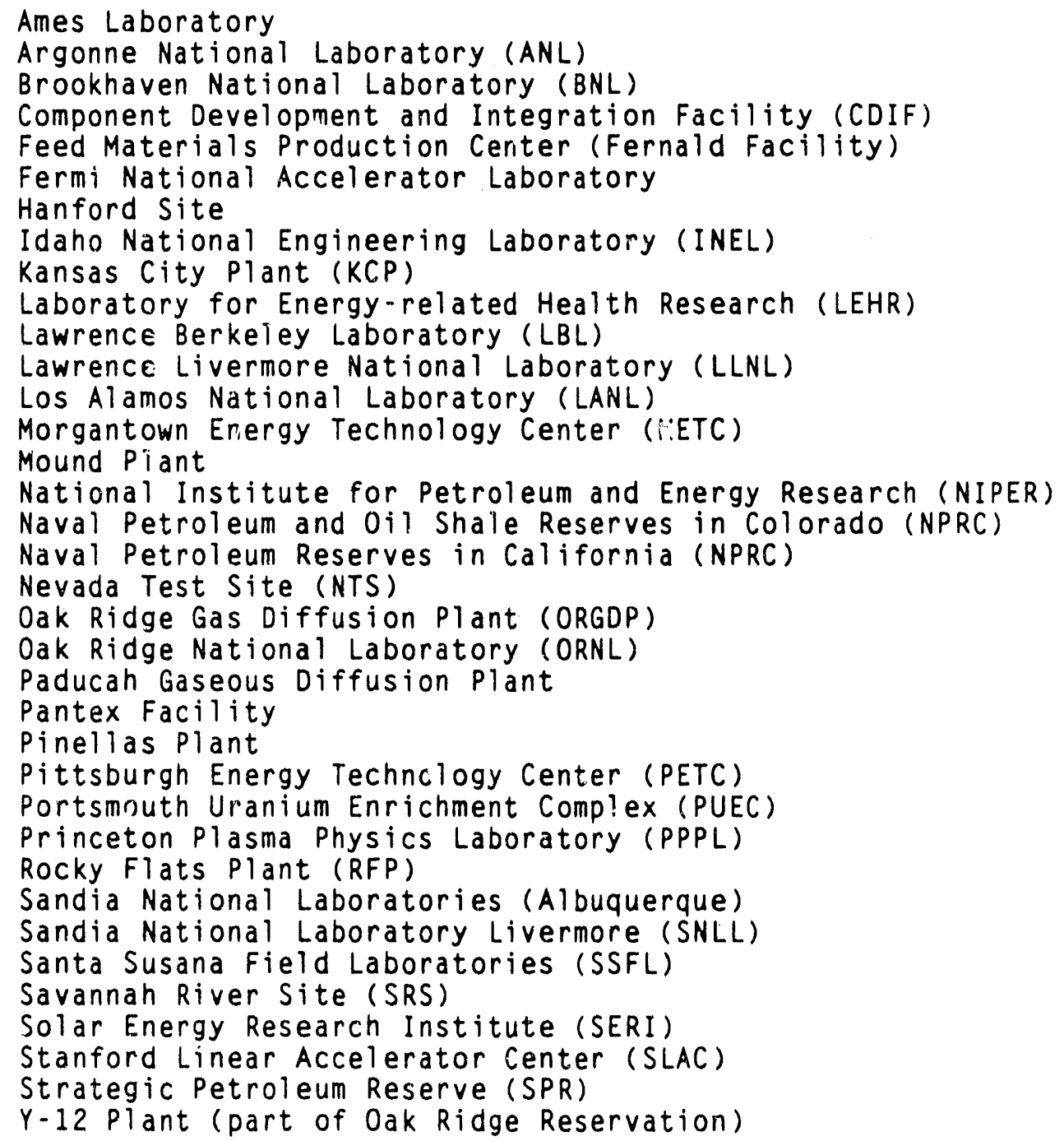

The concentrations of organic compounds identified in Tables $3.1-3.5$ and the presence of other co-contam nants were not available at the time of this writing. Evaluation of specific waste problems for their susceptibility to fungal creatment requires more specific information on contaminant concentrations, co-contaminants, and the current remediation strategy for the waste problem. In addition, treatability studies must be performed with specific waste forms. From the limited DOE waste information available, it is recommended that current Research, Development. Demonstration. Testing and Evaluation (RDDT\&E) for white rot fungus treatment focus on the two primary areas of waste treatment with the potential for the greatest benefit. Fungal 
treatment of high-explosives-contaminated soils could provide an effective alternative to incineration and advancement to the current composting technology, could be rapidly implemented, and has a high likelihood of success based on recent laboratory experiments. Fungal treatment of aqueous wastes with organic contamination from multiple refractory compounds also has a high likelihood for success. Treatment of DOE tank wastes or by-product wastes from treatment of tank wastes would require more extensive laboratory testing and scale-up: however, biological treatment of refractory organics in mixed wastes could provide a cost effective technology with widespread applicability. 


\subsection{BY-PRODUCT INFORMAIION}

An important consideration in evaluating different technologies for the degradation of refractory organic compounds in the environment is the biochemical pathway through which the compounds degrade. Degrading organic contaminants is undesirable if the products formed from degradation pose a greater problem (i.e.. the by-products and/or intermediates are more toxic and/or more refractory). A literature search showed that very litile work has been done to identify the biodegradation by-products and intermediates of refractory organic compounds found on DOE sites. Figure 4.1 presents the

DDT

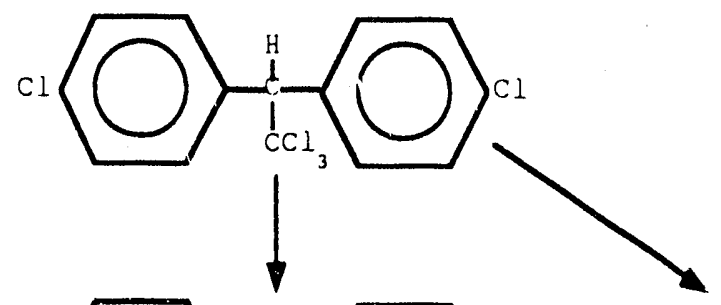

DICOEOL
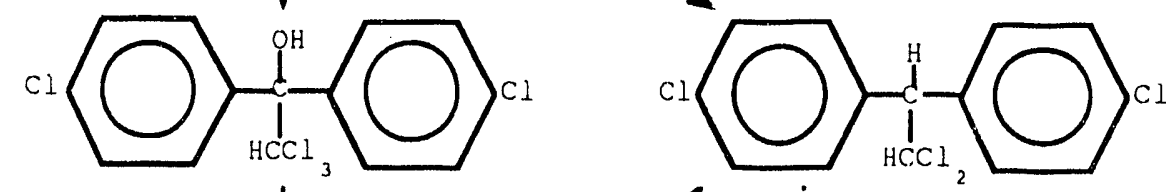

DDD

FW-152
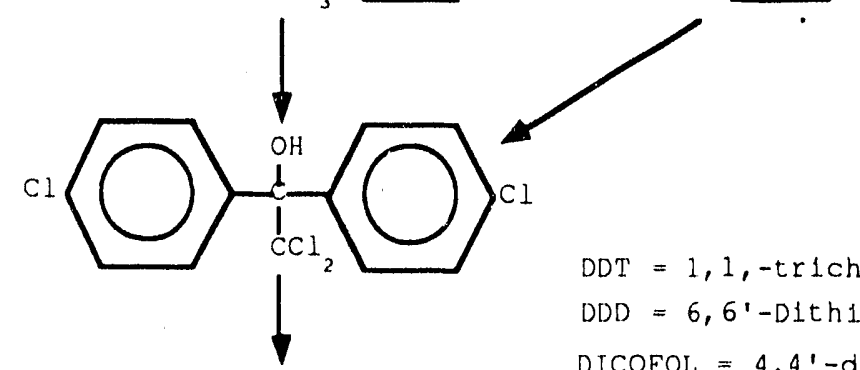

DBP

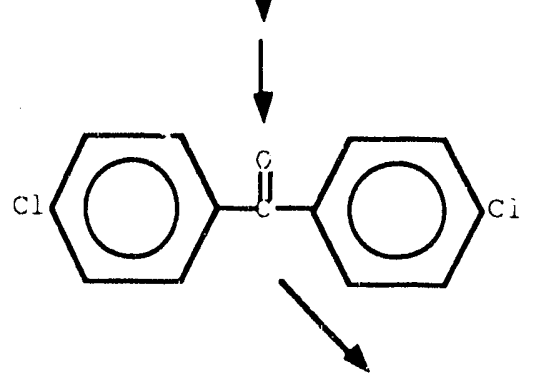

$D D T=1,1,-t r 1 c h l o r o-2,2-b 1 s(p-c h l o r o p h e n y l)$ et hane

DDD $=6,6^{\prime}-$ Dithiobis-?-naphthalenol

DICOFOL $=4,4^{\prime}-$ dichloro-a-(tr1chloromethyl) benzhydrol FW-152 = 2,2-d1chloro-1, 1-b1s (4-chlorophenyl)ethanol

$\mathrm{DBP}=$ dibutyl phthalate

RING CLEAVAGE' PRODUCTS

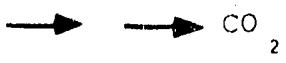

FIGURE 4.1. Proposed Degradation Pathway for DDT by the White Rot Fungus Phanerochaete chrysosporium (Adapted from Bumpus and Aust 1987) 
proposed biochemical pathway for the degradation of DDT by the white rot fungus Phanerochaete chrysosporium (Bumpus and Aust 1987). Ensuring that the end products, possibly ring cleavage products in the case of DDT degradation, are non-hazardous is of primary importance when evaluating the feasibility and benefits of any treatment system. Figure 4.2 presents trie proposed biotransformation scheme for TNT in compost using naturally occurring bacteria (Roy F. Weston. Inc. 1988). Bacterial degradation of INT appears to produce aromatic end products rather than alkanes or carbon dioxide. By comparison. recent fungal degradation studies with TNT have demonstrated mineralization to carbon dioxide (Fernando. Bumpus, and Aust 1990).

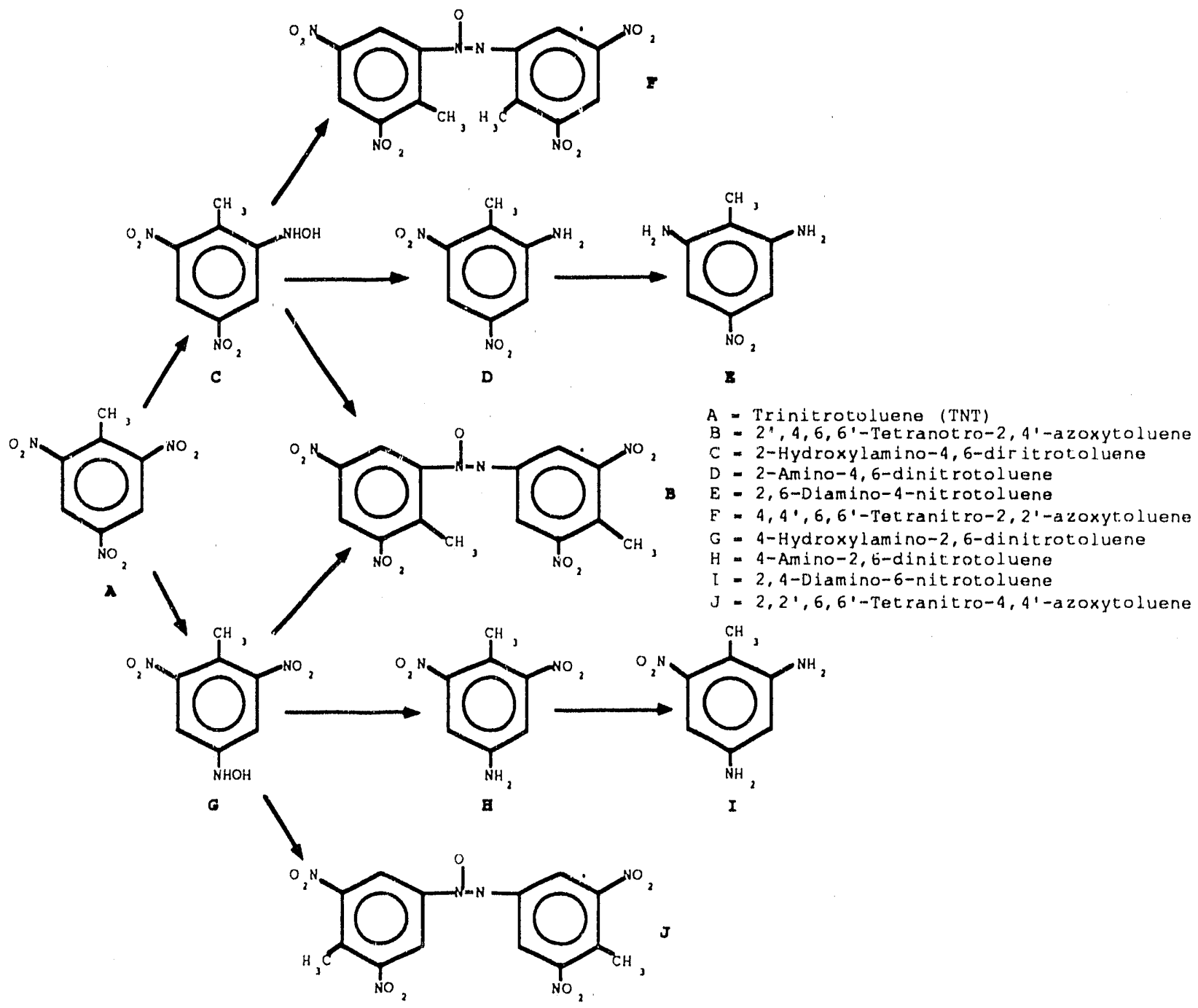

EIGURE 4.2. Proposed Degradation Pathway for TNT. Degradation through naturaliy occurring microorganisms (Adapted from Roy F. Weston. Inc. 1988) 
The scope of this project includes identification of the by-products and intermediates produced by treatment with the white rot fungus. Refractory organic compounds to be studied will be selected based on the following criteria: 1) the organic compound is at a sufficient concentration to warrant bioremediation. 2) the organic compound is a problem at a number of DOE sites. and 3 ) by-products produced from the degradation of the organic compound are non-haizardous. Successful implementation of a fungal treatment process must ensure that the contaminant is degraded to non-hazardous products and that the overall toxicity of the waste is reduced. 


\subsection{PERMITIING AND REGULATORY REQUIREMENTS}

Laboratory-, bencr-, and pilot-scale testing with actual waste (i.e. contaminated soils, groundwaters, or wastewaters) will be conducted as Small Quantity Treatability Tests. NEPA documentation may be required for some of these tests. Field demonstration activities would require NEPA documentation (e.g.. an Environmental Assessment) before initiating the tests. If the field demonstration is conducted at Hanford, the Washington State Department of Ecology may require that field testing be conducted under Hanford's existing Part A Interim Status Treatment, Storage, and Disposal Facility permit for Biological Treatment Test Facilities, or under a new Research. Development. and Demonstration Permit. All testing with simulated and actual waste materials will be conducted in compliance with applicable state and federal regulations and DOE orders. 


\subsection{COST/SCHEDULE INFORMAIION}

The white rot fungus technology will be developed for application to DOE waste problems over a 5-year period, depending on availability of funding. Research will be conducted to identify effective methods and conditions for remediating contaminated soils, wastewaters, and groundwaters using the white rot fungus. The technology will be developed from bench-scale evaluation through field-scale demonstration. The research and development phase of the project will focus on the capability of white rot fungus to degrade DOE pollutants that are present at concentrations requiring remediation, are present at more than one DOE site, and could be destroyed more economically and effectively than with conventional treatment technologies. As identified in the waste information section. the pollutants of interest will include TNT and other high explosives. and aqueous wastes containing multiple refractory organics. Laboratory studies will be designed to determine optimum culture conditions to maximize the rate of degradation. Collaboration with other researchers and industry will be emphasized to avoid the use of unsuccessful methods and to reduce the time required to reach a field demonstration.

Information obtained from laboratory- and bench-scale testing will be used to design and operate pilot-scale processes for in situ or ex situ soil treatment and ex situ groundwater treatment of refractory organics. The task will conclude with a field demonstration of the white rot fungus wastewater. groundwater, or soil treatment processes at a selected DOE waste site.

Equipment used in the pilot-scale testing will be designed for use at a field location. White rot fungus treatment processes would provide a safe and economical means of treating hazardous organic wastes. The technology offers a means of permanently destroying the contaminants on site; therefore, the cost of treatment and potential risk to operating personnel and the public is reduced.

Five subtasks, to be completed in FY-1990 through FY-1994, are required to meet the task objectives:

- Project Management

- Laboratory-scale Treatability Studies

- Bench-scale Kinetics Testing

- Pilot-scale Demonstration

- Field Demonstration 
A description of the subtasks is provilded below. The overall project schedule is shown in Figure 6.1. Project costs are summarized in Table 6.1.

Subtask 1 - Project Management The function of the project management task is to provide project planning. schedule control, and overall administrative and fiscal control for the project. Report preparation. milestone completion, and technology transfer activities are included in the project management task.

Subtask2 - Laboratory-scale Treatability Studies - The research and development phase of the project will focus on the capability of white rot fungus to degrade pollutants which are present at several DOE sites. These pollutants include TNT and other hilgh explosives, and aqueous wastes with multiple refractory organics. Laboratory studies will be designed to determine optimum culture conditions to maximize the rate of degradation.

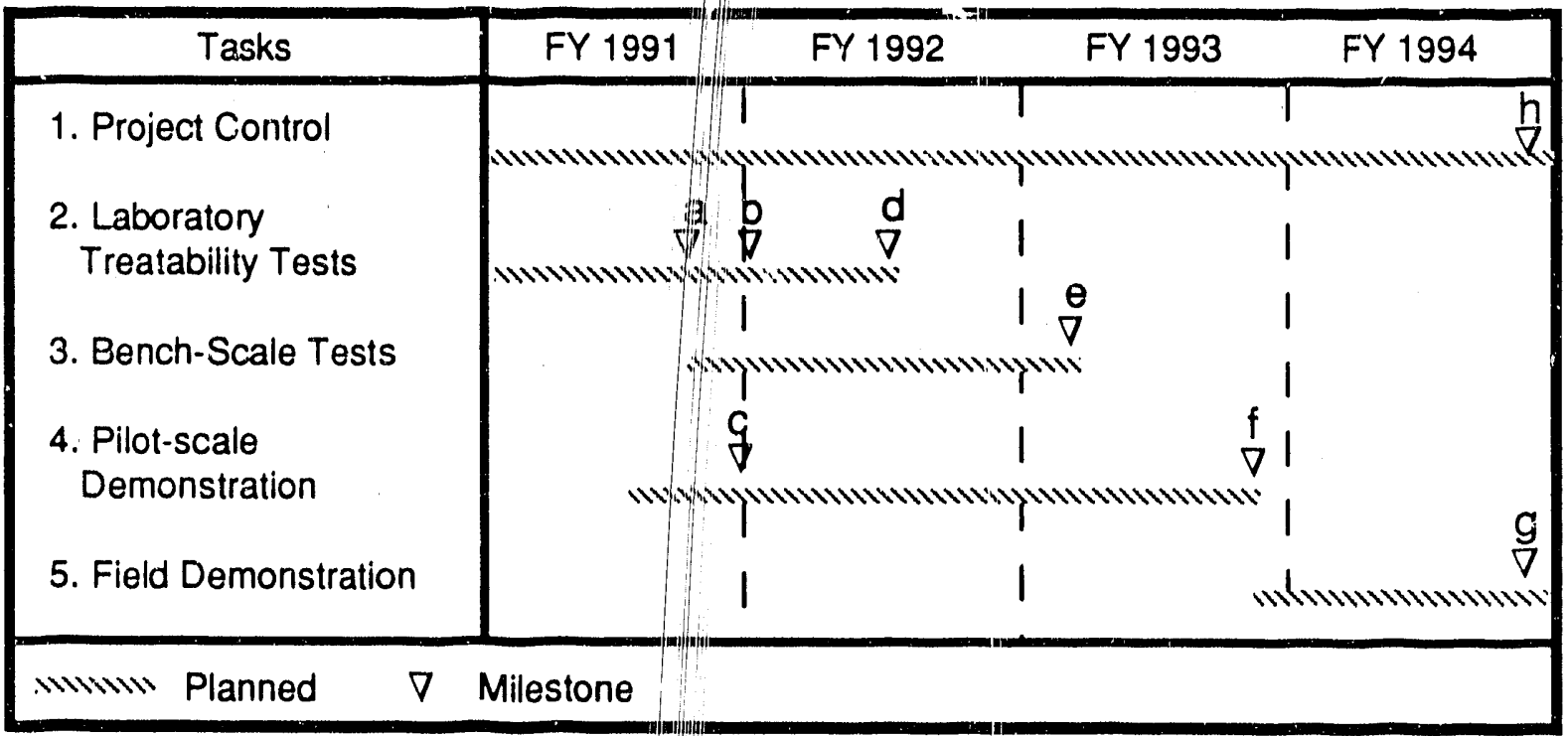

Milestone Explanations:

a. Complete aqueous phase simulated tank waste tests $(6 / 30 / 91-\mathrm{KEY})$

b. Complete side-by-side TNT soil des(ruction test (9/30/91-KEY)

c. Complete design and procurement of demonstration test equipment (9/30/91)

d. Complete laboratory-scale soil studies (3/30/92)

e. Complete bench-scale kinetics tests (11/30/92)

f. Complete pilot-scale demonstration (7/30/93 - KEY)

g. Complete soil treatment field demohistration (9/30/94 - KEY)

h. Issue DT\&E Operational Readines evaluation report (9/3.0/94)

EIGURE 6.1. Project Task and Milestone Schedule 
[ABLE 6.1. Funding Levels by Fiscal Year

\begin{tabular}{|c|c|c|c|c|c|}
\hline Subtask Activities & $\begin{array}{c}F Y \\
1990 \\
\end{array}$ & $\begin{array}{l}\text { FY } \\
1991\end{array}$ & $\begin{array}{l}F Y \\
1992\end{array}$ & $\begin{array}{l}F Y \\
1993 \\
\end{array}$ & $\begin{array}{c}F Y \\
1994\end{array}$ \\
\hline Subtask 1 - Project Management & 48 & 60 & 60 & 60 & 60 \\
\hline $\begin{aligned} \text { Subtask } 2 \text { - Laboratory-scale } & \\
& \text { Treatability Studies }\end{aligned}$ & 65 & 90 & 60 & 0 & 0 \\
\hline 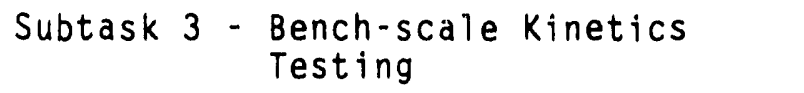 & 0 & 60 & 40 & 60 & 0 \\
\hline Subtask 4 - Pilot-scale Demonstration & 0 & $100(a)$ & 150 & 150 & 0 \\
\hline Subtask 5 - Field Demonstration & e & - & le & 150 & 300 \\
\hline TOTAL & 113 & 310 & 310 & 420 & 360 \\
\hline
\end{tabular}

(a) Capital Equipment funding required for pilot-scale equipment.

Tests have been conducted to confirm TNT destruction, and a subcontract with Dr. Ron Crawford of the University of Idaho has been initiated. Dr. Crawford will conduct side-by-side comparisons of bacterial and fungal composting processes for TNT destruction in soils. Additional studies will be conducted in FY-1991 using aqueous systems with the fungus in either a suspension culture or attached to a support matrix. Data providing concentrations for the contaminants identified in Tables 3.1-3.5 will be obtained if available to identify several contaminants of interest to be studied for susceptibility to degradation. Based on the results of these tests, and the environmental medium of the contaminants, soil studies will be initiated in FY-1991 to determine the technical feasibility of both in situ and ex situ soil treatment. Factors such as soil water potential, nitrogen concentration, and temperature have been shown to affect the growth of white rot fungus in soils. Soil studies will focus on the effect of these factors as well as those identified in aqueous laboratory studies. Tests will be conducted using both shallow soil beds where composting or tilling is feasible, and deeper soil columns where injection methods may be required to induce fungal growth. Tests to evaluate the effect of radionuclides on the biodegradation will be conducted if applicable for the selected contaminants.

Subtask 3 - Bench-scale Kinetics Testing - Results of the laboratory studies will be used as a basis for bench-scale tests using a proven 
bioreactor system for the treatment of groundwaters or wastewaters, and simulated soil beds or columns for the treatment of contaminated soils. Depending on the parameters identified in the laboratory tests, a series of bench-scale tests will be conducted to collect kinetic data essential for scale-up to a pilot-scale treatment process. The primary concern will be uniformity of fungal growth and pollutant degradation as a function of soil depth or bioreactor configuration. These tests will use various methods for initiating and maintaining fungal growth to determine the most efficient procedures and processing techniques.

Subtask 4 - Pilot-scale Demonstration - Kinetic data and operating experience from the bench-scale tests will be used to evaluate the techaical and economic feasibility of biodegradation using white rot fungus. In addition, a pilot-scale process or processing equipment will be procured. Based on the cost effectiveness of other bioremediation technologies, it is anticipated that pilot-scale testing will be warranted. The pilot-scale system would be initially tested using a simulated waste stream, and tested later'wsing contaminated groundwater. Wastewater. soil, or sluds's.

Subtask 5 - Field Demonstration - Following pilot-scale testirg, either wastewater, groundwater, or soil treatment processes will be demonstrated on a selected DOE waste problem. Equipment used in the pilot-scale testing will be designed for use at a field location. 


\subsection{REFERENCES}

Arjmand. M. and H. Sandermann, Jr. 1985. Mineralization of CholoroanilinelLignin Conjugates and of Free Chloroanilines by the White Rot Fungus Phanerochaete chrysosporium." Jeurnal of Agricultural Food Chemistry 33:1055-1060.

Bumpus. J. A. 1989. "Biodegradation of Polycyclic Aromatic Hydrocarbons by Phanerochaete chrysosporium." Applied and Environmental Microbiology $55: 154-158$.

Bumpus. J. A. and S. D. Aust. 1987. "Biodegradation of DDT [1,1,1 trichloro - 2.2 - bis(4 - chlorophenyl)ethane] by the White Rot Fungus Phanerochaete chrysosporium." Apolied and Environmental Microbiology $53: 2001-2008$.

Choi. J.and S. Aomine. 1974a. "Adsorption of Pentachlorophenol by Soills." Seil Science and Plant Nutrition 20:135-144.

Choi, J. and S. Aomine. 1974b. Mechanisms of Pentachlorophenol Adsorption by Soils." jeil Science and Plant Nutrition 20:371-379.

Crawford, R. L. and W. W. Mohn. 1985. Micrabial Remaval of Pentachlorophenol From Soil Using a Flavobacterium." Enzyme Micrabial Technology 7:617-620.

Droppo, J. G.. Jr.. J.W. Buck, D. L. Strenge, and M. R. Siegel. 1990. Analys is of Heal th Impacts Inputs to the U. $S$. Department of Energy's $R$ isk Information System. PNL-7432. Pacific Northwest Laboratory. Richland. Washington.

Eaton. D. C. 1985. Mineralizdtion af Polychlorinated Biphenyls by Phanerochaete chrysospcrium: a Ligninolytic Fungus." Enzyme Microbial Iechnelegy $7: 194-196$.

Edgetill, R. U. and R. K. Finn. 1983. "Microbial Treatment of Soil to Remove Pentachlorophenol." Applied and Environmental Microbiology 45:1122-1125.

Fernando. T.. J. A. Bumpus and S. D. Aust. 1990. "Biodegradation of TNT (2.4.6 - Trinitrotoluene) by Phanerochaete chrysosporium." Apolied and Envirsonmental Microbiology $56: 1666 \cdot 1671$.

Hammel, K. E.. B. Kalyanaraman and T. K. Kirk. 1986. "Oxidation of Polycyclic Aromatic Hydrocarbons and Dibenzo[p]-dioxins by Phanerochaete chrysosporium Ligninase." The Jeurnal of Biolegical Chemistry 261:1694816952 .

Huynh V.. H. Chang. T. W. Joyce, and T. K. Kirk. 1985. "Dechlorination of Chloro-organics by a White-Rot Fungus." Tappi Journal 68:98-102.

Klemm. M. J. 1988. Inventory of Chemicals Used at the Hanford Preduction Plants and Suppert Operations. WHC-EP-01726188. Westinghouse Hanford Company. Richland, Washington. 
Kohler. A.. A. Jager. H. Willershausen and H. Graf. 1988. "Extracellular Ligninase of Phanerochaete chrysosporium Burdsall Has No Role in the Degradation of DDT." Applied and Microbiology Biotechnology 29:618-620.

Lamar. R. T., M. J. Larsen. T. K. Kirk and J. A. Glaser. 1987. "Growth of the White-Rot Fungus Phanerochaete Chrysosporium in Soil." Land Disposal. Remedial Action. Incineration and Treatment of Hazardous Waste: Proceedings of the 13th Annual Research Symposium: May 6-8, pp. 419-424.

Lamar. R. T.. J. A. Glaser and T. K. Kirk. 1990. "Fate of Pentachlorophenol $(P C P)$ in Sterile Soils Inoculated with White-Rot Basidiomycete Phanerochaete Chrysosporium: Mineralization, Volatilization and Depletion of PCP." Soil Bielegy and Biechemistry 22:433-440.

Lewandowski, G. A.. P. M. Armenante, and D. Pak. 1990. "Reactor Design for Hazardcus Waste Treatment Using a White Rot Fungus." Water Resources 24:7582 .

Loorey, B. B.. J. B. Pickett. C. M. King. W. G. Holmes. W. F. Johnson and J. A. Smith. 1987. Environmental Information Document: Selection of Chemical Constituents and Estimation of Inventories for Environmental Analys is of Savannah River Plant Waste Sites. DPST-86-291. E. I. du Pont de Nemours \& Co.. Savannah River Laboratory, Aiken, South Carolina.

Martin Marietta Energy Systems. Inc. 1989. lak Ridge Reservation Environmental Report for 1988. ES/ESH-8/V2, Vol. 2. Oak Ridge National Laboratory. Oak Ridge. Tennessee.

Mileski. G. J.. J. A. Bumpus. M. A. Jurek and S. D. Aust. 1988. "Biodegradation of Pentachiorophenol by the White Rot Fungus Phanerochaete chrysosporium." Applied and Environmental Microbiology $54: 2885-2889$.

Pacific Northwest Laboratory (PNL). 1987. Enyirenmental Monitoring at Hanford for 1986. PNL-6120. Pacific Northwest Laboratory, Richland. Washington.

Remediation Technologies. Inc. 1990. Final Report (August 1, 1990). Evaluation of Composting Implementation. Prepared for U.S. Army Toxic and Hazardous Materials Agency (USATHAMA). APG. Maryland.

Rosiers. P. E. 1987. "Evaluation of Technology for Waste and Soils Contaminated with Dioxins. Furans, and Related Substances." Jeurnal of Hazardeus Materials 14:119-133.

Roy F. Weston. Inc. 1988. Field Demonstration-Composting of Explosives Centaminated Sediments at the Louisiana Army Ammunition Plant (LAAP). Report Number AMXTH-IR-TE-88242. West Chester. Pennsylvania.

Steiert. J. G. and R. L. Crawford. 1985. MMicrobial Degradation of Chlorinated Phenols." Irends in Biotechnology $3: 300-305$.

Strenge, D. L.. and S. R. Peterson. 1989. Chemical Databases for the Multimedia Environmental Pollutant Assessment System (MEPAS): Version 1. PNL-7145. Pacific Northwest Laboratory. Richland, Washington. 
Superfund Amendments and Reauthorization Act of 1986 (SARA), Title III. Section 313. 1986. 42 USC 9615 et seq.

U.S. Army Toxic and Hazardous Materials Agency. 1989. Proceedings for the 6-8 September. 1989. Workshop on "Composting of Explosives Contaminated Soils," Report Number CETHA-TS-SR-89276. APG, Maryland.

U.S. Department of Energy (DOE). 1987. Einal Environmental Impact Statement: Dispesal of Hanford Defense High-Level. Transuranic and Tank Wastes. DOE/EIS-0013, U.S. DOE, Washington, D.C.

U.S. Environmental Protection Agency. 1976. "Quality Criteria for Water." Washington, D.C.

U.S. Environmental Protection Agency. 1987. "National Primary Drinking Water Regulations." U.S. 40 CFR 141.

U.S. Environmental Protection Agency. "National Primary Drinking Water Regulations: Volatile Synthetic Organic Chemicals and Microorganisms." Federal Register. 50 FR 469021985. 

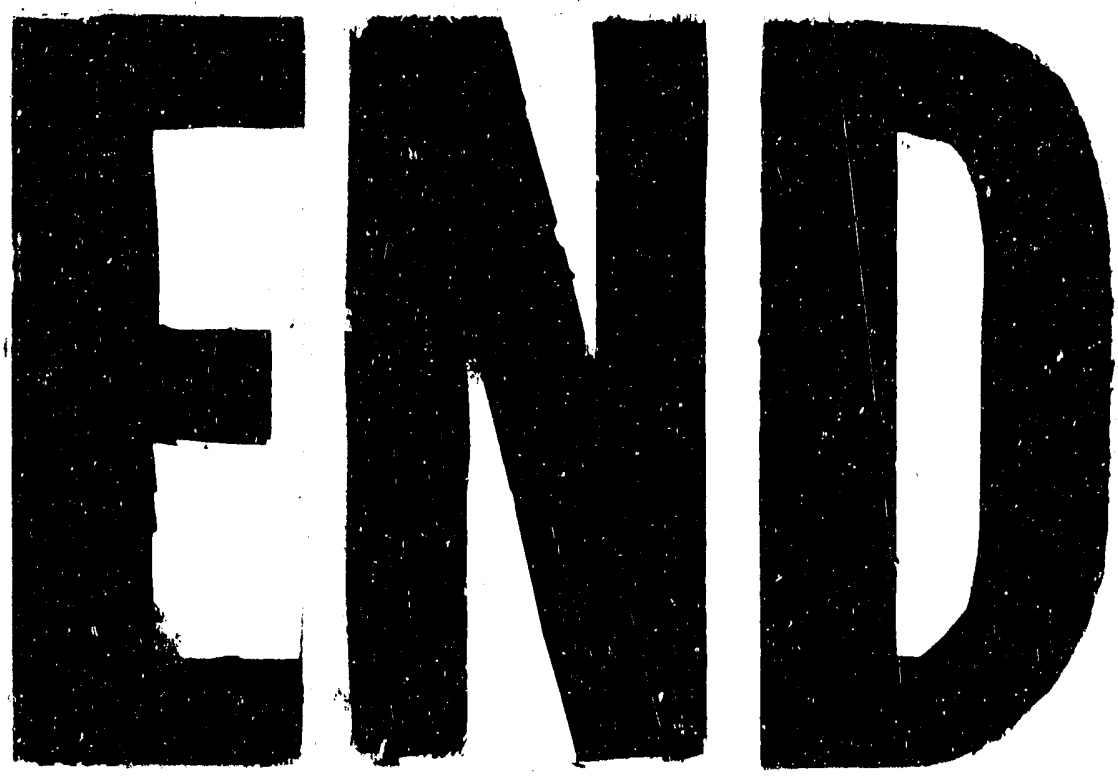

4
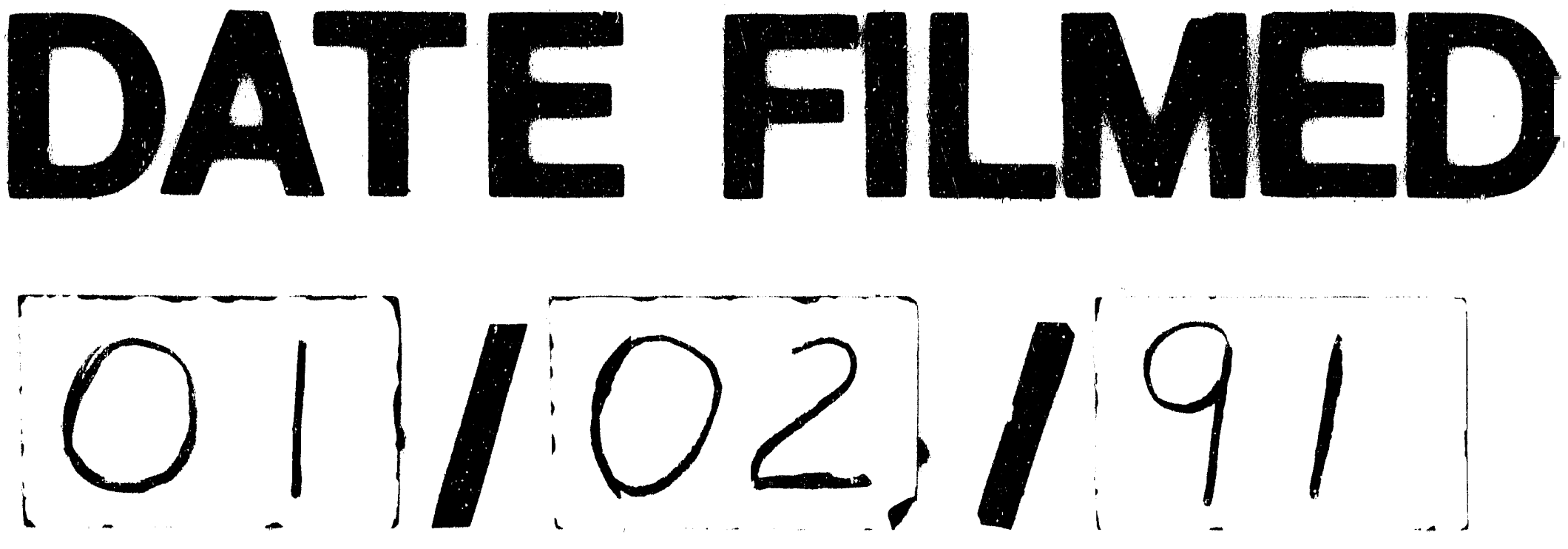
